\title{
Vibrational Analysis of Microtubules Embedded within Viscoelastic Medium using Orthotropic Kelvin like Model
}

(Analisis Getaran Bermikrotubul Tertanam dalam Medium Likat Kenyal menggunakan Model seperti Ortotropisme Kelvin)

\author{
MuHAMmad SAFEER \& MUHAMMAD TAJ*
}

\begin{abstract}
Microtubules, the key components of cytoskeleton of all living cells, are important for maintaining the cell shape and transporting the cellular organelles. Understanding the mechanics of microtubules is very important for these functions. Mechanics of these components are greatly affected when they are embedded in cells. To understand the mechanical properties of microtubules in living cells, we developed an orthotropic-Kelvin like model and investigated the vibrational behavior when they are embedded in surrounding elastic medium. We considered them as orthotropic elastic shell and its surrounding elastic matrix as Kelvin model. We found that due to mechanical coupling of these components with the elastic medium, the flexural vibration is increased and radial frequencies in all modes are increased considerably while other vibrational modes are not affected that much.
\end{abstract}

Keywords: Elastic medium; Kelvin foundation; microtubules; vibration

\section{ABSTRAK}

Mikrotubul merupakan komponen utama sita rangka bagi semua sel hidup dan adalah penting untuk mengekalkan bentuk sel dan membawa organel sel. Memahami mekanik mikrotubul adalah sangat penting bagi fungsi tersebut. Mekanik untuk komponen ini adalah sangat terkesan apabila mereka terbenam di dalam sel. Untuk memahami sifat mekanik mikrotubul dalam sel hidup, kami telah membangunkan model seperti Ortotropik-Kelvin dan mengkaji tingkah laku getaran apabila ia dibenamkan di persekitaran medium kenyal. Kami menganggap ia sebagai kelongsong kenyal Ortotropik dan persekitaran matrik kenyal sebagai model Kelvin. Kami telah mendapati bahawa kesan daripada gandingan mekanik oleh komponen ini dengan medium kenyal dan getaran lentur adalah meningkat dan frekuensi radial di dalam semua mod adalah meningkat dengan ketara manakala mod-mod getaran yang lain tidak begitu banyak yang terkesan.

Keywords: Asas Kelvin; getaran; medium kenyal; mikrotubul

\section{INTRODUCTION}

Cytoplasm is present in all living cells with a complicated network of proteins fibers that extend throughout the cytoplasm from nucleus to cell membrane (Hardin 2015). This system of cytoskeleton of different organisms consists of similar proteins network. In eukaryotes, the cytoskeleton is a dynamic structure consists of three major proteins fibers, microtubules (MTs), actin-filaments (F-actin) and intermediate filaments (IFs) which are responsible for the fast growth or disassembly depends upon the requirements of the cell at a certain period (Chung-Davidson et al. 2010). Among the three proteins fibers, MTs are the stiffest components of cytoskeleton, which are largely responsible for cell shape and structure to the cell (Kreider \& Blumberg 2005). Structurally, MTs are hollow cylinders with inner and outer diameters of $13 \mathrm{~nm}$ and $25 \mathrm{~nm}$, respectively, whose length can vary from tens of nanometers to hundreds of microns (Feldhendler 2002). The basic structural units of MTs are tubulin dimmers of proteins bonded together longitudinally to form 13 parallel protofilaments (Morehouse et al. 2000; VanBuren et al. 2002).
The roles of the cytoskeleton MTs include mechanical support, organization of the cytoplasm, transport, motility and in helping chromosome separation (Shah et al. 1998; Sharma et al. 2019). In developing neurons, MTs are known as neurotubules and they can adapt the dynamics of F-Actin, another component of the cytoskeleton (Zhao et al. 2017). MTs play a role in movement of chromosomes during cell division and creation of mitotic spindle. In compliant with IF and F-actin, MTs are responsible for stabilization of the cell (Morehouse et al. 2000; Zheng et al. 1993). Moreover, MTs translate and act as electrical transmissions lines to input the information carried by electrophysiological impulses that enter into the brain cortex (Adames \& Cooper 2000; Forbes et al. 2006; Zhang et al. 2003). MTs vibrate while performing above mentioned functions, therefore vibration of MTs has been the main topic of interest for many researchers (Leonova et al. 2003; Shen \& Andrews 2011; Sirenko et al. 1996). In these studies, vibration of MTs is discussed considering it as free, i.e. without medium. Their results indicate that frequencies of vibration for different modes are less than 
experimentally found results while MTs are in natural medium (Felgner et al. 1997). As mechanical properties of MTs are greatly affected when they embedded in the elastic medium (Brangwynne et al. 2006; Nogales et al. 1999), therefore, the mechanics of MTs, when coupled with elastic medium, has been the topic of numerous researchers during the last decade (Taj \& Zhang 2012, 2011; Zhou et al. 2010). Wang et al. (2006), discussed the vibration of free MTs using orthotropic elastic shell model, because the longitudinal bond between tubulin dimmers along the $\mathrm{PF}$ is much stronger than the lateral bond between $\alpha \beta$-tubulin dimmers along the PF is much stronger than the lateral bond between the adjacent PFs (Schoutens 2005; Taj \& Zhang 2014), in particular, modulus of elasticity in longitudinal direction is much stronger than the circumferential and shear modulus by few orders of magnitude (Nogales et al. 1999), therefore, it is suggested that instead of isotropic elastic shell model, it is better to use 'orthotropic elastic shell model' for MTs more accurately. Moreover, a good agreement has been found between 'orthotropic elastic shell model' and discrete data and experimental findings in the literature (Leonova et al. 2003; Shen \& Andrews 2011). Later, Taj and Zhang (2012), used the same model to study dispersion relation of MTs within medium using Pasternak model for the medium. But as we know that MTs are embedded in cytoplasm which is compose of viscous and elastic component, therefore, it is better to model the surrounding medium by Kelvin model (Meyers \& Chawla). By combining orthotropic elastic shell model with Kelvin model, we developed 'orthotropic elastic kelvin like model' to study the vibrational behavior of embedded MTs.

Some details of orthotropic elastic shell model and Kelvin model are given in the next section and combination of these two models is used to obtain 'Orthotropic elastic Kelvin like model'. While in the subsequent section, orthotropic elastic Kelvin like model is used to analyze the vibration of MTs in viscoelastic medium and results obtained are compared to those, based on vibration of MTs in the free medium. Finally at the end, the results obtained are summarized.

\section{METHODS}

\section{ORTHOTROPIC ELASTIC SHELL MODEL}

MTs are formed by 13 parallel PFs joined together laterally. The basic units of these PFs are tubulin dimmers joined together strongly along the PF. While the bonds between these dimmers in lateral direction are not too much strong as compared with the bonds along the PF. Moreover, the longitudinal bond between $\alpha \beta$-tubulin dimmers along the $\mathrm{PF}$ is much stronger than the lateral and circumferential one (Van Buren \& Erskine 2002). On the basis of these ideas, it is suggested that an orthotropic elastic shell model is developed to study the mechanical properties of MTs rather than the isotropic elastic shell model (Sirenko et al. 1996).
The expression for orthotropic elastic shell model is written by using four independent material constants, longitudinal modulus $E_{x}$, circumferential modulus $E_{\theta}$, shear modulus, $G_{x \theta}$ and piosson ratio, $v_{x}$ along longitudinal direction (Kiyoi et al. 1999; Schoutens 2005). Other material constants such as Poisson ratio, $v_{\theta}$ along circumferential direction, in plane stiffnesses $K_{x}, K_{\theta}$ and $K_{x \theta}$ along longitudinal, circumferential and shear direction and three effective bending stiffnesses $D_{x}, D_{\theta}$ and $D_{x \theta}$ along longitudinal, circumferential and shear direction can be written by using these material constants such as,

$$
\begin{aligned}
& \frac{v_{\theta}}{v_{x}}=\frac{E_{\theta}}{E_{x}}, K_{x}=\frac{E_{x} h}{1-v_{x} v_{\theta}}, K_{\theta}=\frac{E_{\theta} h}{1-v_{x} v_{\theta}}, K_{x \theta}=G_{x \theta h}, \\
& D_{x}=\frac{E_{x} h_{0}^{3}}{12\left(1-v_{x} v_{\theta}\right)}, D_{\theta}=\frac{E_{\theta} h_{0}^{3}}{12\left(1-v_{x} v_{\theta}\right)}, D_{x \theta}=\frac{G_{x \theta} h_{0}^{3}}{12}
\end{aligned}
$$

$h$ and $h_{0}$ are equivalent and effective thicknesses of cross section of MTs (Yang et al. 2006). Therefore, for these thicknesses $h$ and $h_{0}$ 'orthotropic elastic shell model' depends upon four material constants $E_{x}, E_{\theta}, G_{x \theta}$ and $v_{x}$ as given in Table 1 for MTs.

Orthotropic MTs within viscoelastic medium are modeled by the governing equations (Pet-Soede et al. 1999) and (Burton \& Forbes 1960)

$$
\begin{gathered}
\left\{\begin{array}{l}
r^{2} \frac{\partial^{2}}{\partial x^{2}}+ \\
\beta(1+\gamma) \cdot \frac{\partial^{2}}{\partial \theta^{2}}
\end{array}\right\} \cdot u+\left\{\left(\alpha v_{x}+\beta\right) \cdot r \cdot \frac{\partial^{2}}{\partial x \partial \theta}\right\} \cdot v+\left\{\begin{array}{l}
-\alpha v_{x} r \cdot \frac{\partial}{\partial x} \\
+\gamma \cdot r^{3} \cdot \frac{\partial^{3}}{\partial x^{3}} \\
-\beta \cdot \gamma \cdot r \cdot \frac{\partial^{3}}{\partial x \partial \theta^{2}}
\end{array}\right\} \\
w+\frac{r^{2}}{\rho h S_{L}^{2}} P_{x}=\left(\frac{r}{S_{L}}\right)^{2} \cdot \frac{\partial^{2} u}{\partial t^{2}} \\
\left\{\left(\alpha v_{x}+\beta\right) \cdot r \cdot \frac{\partial^{2}}{\partial x \partial \theta}\right\} \cdot u+\left\{\begin{array}{l}
\alpha \cdot \frac{\partial^{2}}{\partial \theta^{2}} \\
+\beta \cdot(1+3 \gamma) \cdot r^{2} \cdot \frac{\partial^{2}}{\partial x^{2}}
\end{array}\right\} \cdot v+\left\{\begin{array}{l}
-\alpha \cdot \frac{\partial}{\partial \theta} \\
+\gamma \cdot\left(\alpha v_{x}+3 \beta\right) \cdot r^{2} \cdot \frac{\partial^{3}}{\partial x^{2} \partial \theta}
\end{array}\right\} \\
w+\frac{r^{2}}{\rho h S_{L}^{2}} P_{\theta}=\left(\frac{r}{S_{L}}\right)^{2} \cdot \frac{\partial^{2} v}{\partial t^{2}}
\end{gathered}
$$$$
\begin{aligned}
& \left\{\begin{array}{l}
\alpha v_{x} r \cdot \frac{\partial}{\partial x} \\
-\gamma \cdot r^{3} \cdot \frac{\partial^{3}}{\partial x^{3}}+ \\
+\gamma \cdot \beta \cdot r \cdot \frac{\partial^{3}}{\partial x \partial \theta^{2}}
\end{array}\right\} \cdot u+\left\{\begin{array}{l}
\alpha \cdot \frac{\partial}{\partial \theta} \\
-\gamma \cdot\left(\alpha v_{x}+3 \beta\right) \cdot r^{2} \cdot \frac{\partial^{3}}{\partial x^{2} \partial \theta}
\end{array}\right\} \cdot v+ \\
& \left\{\begin{array}{l}
-\gamma \cdot r^{4} \cdot \frac{\partial^{4}}{\partial x^{4}} \\
-2 \gamma \cdot\left(\alpha v_{x}+2 \beta\right) \cdot r^{2} \cdot \frac{\partial^{4}}{\partial x^{2} \partial \theta^{2}} \\
-\alpha \cdot \gamma \cdot\left(\frac{\partial^{2}}{\partial \theta^{2}}+1\right)^{2}-\alpha
\end{array}\right\} \cdot w+\frac{r^{2}}{\rho h S_{L}^{2}} P_{w}=\left(\frac{r}{S_{L}}\right)^{2} \cdot \frac{\partial^{2} w}{\partial t^{2}}
\end{aligned}
$$ 
$x$ and $\theta$ are axial and circumferential coordinates, respectively; $u, v$ and $w$ are axial, circumferential and radial (inward positive) deflection, respectively; $\rho$ is the mass density; and $r$ is the average radius of MTs. The other constants are defined as,

$$
\begin{aligned}
& \alpha=\frac{v_{\theta}}{v_{x}}=\frac{E_{\theta}}{E_{x}}=\frac{K_{\theta}}{K_{x}}=\frac{D_{\theta}}{D_{x}}, \\
& \beta=\frac{G_{x \theta}}{E_{x}} \approx \frac{G_{x \theta}}{E_{x}}\left(1-\alpha v_{x}^{2}\right)=\frac{D_{x \theta}}{D_{x}}=\frac{K_{x \theta}}{K_{x}}\left(\alpha v_{x}^{2} \rightarrow 0\right), \\
& \gamma=\frac{h_{0}^{3}}{12 h r^{2}} \text { and } S_{L}=\sqrt{\frac{K_{x}}{\rho h}} \approx \sqrt{\frac{E_{x}}{\rho}} .
\end{aligned}
$$

$S_{L}=\sqrt{\frac{K_{x}}{\rho h}} \approx \sqrt{\frac{E_{x}}{\rho}}$ is longitudinal sound speed. Thus, for the given $h$ and $h_{0}$, the orthotropic elastic shell model for MTs is characterized by four parameters $E_{x}\left(\right.$ or $\left.\mathrm{S}_{\mathrm{L}}\right), v_{x}, \alpha$ and $\beta$. Orthotropic shell model reduces to isotropic shell model if the parameters $\alpha$ and $\beta$ are given by,

$$
\alpha=1 \text { and } \beta=(1-v) / 2=0.35
$$

\section{KELVIN VOIGT MODEL}

The Kelvin Voigt model can be represented purely by a viscous damper and purely elastic spring connected in parallel.

For the viscoelastic medium of MTs, the model takes the form:

$$
\begin{aligned}
& P_{x}=-K u-\eta \frac{\partial u}{\partial t} \\
& P_{\theta}=-K v-\eta \frac{\partial v}{\partial t} \\
& P_{w}=-K w-\eta \frac{\partial w}{\partial t}
\end{aligned}
$$

$P_{x}, P_{\theta}, P_{w}$ are the pressures around the MTs in longitudinal, circumferential and radial direction, respectively, exerted by the surrounding viscoelastic medium. $K$ and $\eta$ are the elastic and viscous coefficients, respectively. The negative sign indicates that the pressures are in opposite to the vibration amplitude. The specific values of viscoelastic parameters, $K$ and $\eta$ are shown in Table 2 (Boykov et al. 2004; Meyers \& Chawla 1999).

\section{ANALYSIS OF VIBRATION OF MTS IN VISCOELASTIC MEDIUM}

Considering MTs as simply supported at both the ends, the solution of governing (2) is of the form,

$$
\begin{aligned}
& u(x, \theta, t)=U \cdot \operatorname{Cos} k_{x} x \cdot \operatorname{Cosn} \theta \cdot e^{i \omega t} \\
& v(x, \theta, t)=V \cdot \operatorname{Sin} k_{x} x \cdot \operatorname{Sinn} \theta \cdot e^{i \omega t} \\
& w(x, \theta, t)=W \cdot \operatorname{Sin} k x x \cdot \operatorname{Cosn} \theta \cdot e^{i \omega t}
\end{aligned}
$$

$\mathrm{U}, \mathrm{V}$ and $\mathrm{W}$ represent the vibration amplitude in longitudinal, circumferential and radial direction respectively, $k_{x}$ is the wave vector and is the angular frequency which is related to frequency $f$ by the relation, $\omega=2 \pi f$.

On substitution of (4) and (5) in (2) we obtained the following algebraic equations,

$$
\begin{aligned}
& \left\{\xi-\Omega^{2}+n^{2} \beta+n 2 \beta \gamma+k^{2}\right\} U+\left\{-n \beta k-n k \alpha v_{1}\right\} V \\
& +\left\{-n^{2} \beta \gamma k+\gamma k^{3}+k \alpha v_{1}\right\} W=0\left\{-n \beta k-n k \alpha v_{1}\right\} U+ \\
& \left\{\xi-\Omega^{2}+n^{2} \alpha+\beta k^{2}+3 \beta \gamma k^{2}\right\} V+\left\{-n \alpha-3 n \beta \gamma k^{2}-\right. \\
& \left.n \gamma k^{2} \alpha v_{1}\right\} W=0\left\{-n^{2} \beta \gamma k+h \gamma k^{3}+k \alpha v_{1}\right\} U+\{-n \alpha \\
& \left.-3 n \beta \gamma k^{2}-n \gamma k^{2} \alpha v_{1}\right\} V+\left\{\xi-\Omega^{2}+\alpha+\alpha \gamma-2 n^{2} \alpha \gamma+\right. \\
& \left.n^{4} \alpha \gamma+4 n^{2} \beta \gamma k^{2}+\gamma k^{4}+2 n^{2} \gamma \rho k^{2} \alpha v_{1}\right\} W=0
\end{aligned}
$$

where $\Omega=\frac{r \omega}{S_{L}}$ is dimensionless frequency, $\mathrm{k}=\mathrm{rk}_{\mathrm{x}}$ is dimensionless wave vector. Moreover,

$$
\xi=\frac{r^{2}}{h \rho S_{L}^{2}} \operatorname{Abs}[K+i n \omega]
$$

is the nondimensional elastic and viscous parameter. The frequency determinant of the system (6) is of the form,

$$
H(n, k, \Omega)_{3 \times 3}
$$

$H$ is the coefficient matrix of system (6). The nontrivial solution of system (6) exists for unknown U, V and W only when

TABLE 1. Numerical values of material constants

\begin{tabular}{lcc}
\hline Parameters & Symbols & Numerical values \\
\hline Young's modulus & $E_{x}$ & $0.5-2.0 \mathrm{Gpa}$ \\
Circumferential Modulus & $E_{\theta}$ & $1-4 \mathrm{Mpa}$ \\
Shear Modulus & $G_{x \theta}$ & $1 \mathrm{Mpa}$ \\
Poisson's ratio in axial direction & $v_{x}$ & 0.3 \\
Mass density per unit volume & $\rho$ & $1.47 \mathrm{~g} /$ \\
Equivalent thickness & $h$ & $2.7 \mathrm{~nm}$ \\
Effective thickness & $h_{0}$ & $1.6 \mathrm{~nm}$ \\
\hline
\end{tabular}

Orthotropic MTs within viscoelastic medium are modeled by the governing equations (Pet-Soede et al. 1999) and (Burton \& Forbes 1960) 


$$
\operatorname{det}\left[H(n, k, \Omega)_{3 \times 3}\right]=0
$$

Solving (8), one gets $\Omega$ as the function of $n$ and $k$ with elastic and viscous effect as $\xi$. The frequency $f$ is calculated by the relation, $f=\left(\frac{S_{L}}{2 \pi}\right) \Omega$

\section{RESULTS}

MTs embedded within surrounding elastic matrix (viscoelastic medium) are analyzed to determine the vibrational behavior under the influence of foundation parameters (elastic and viscous) $E$ and $\eta$ and the obtained results are summarized in the form of tables and figures as follows:

Table 3 shows the comparisons of the numerical results for all three modes of frequencies in longitudinal, radial and torsional directions for free medium and within medium for orthotropic microtubules.

\section{DISCUSSION}

Figure 1 shows the dispersion curves for embedded and free MTs between dimensionless frequencies and wave vector k for axisymmetric mode $n=0$, when $E=4.32 \times 10^{4}$ $\mathrm{kg} / \mathrm{m}^{2} s$, and $\eta=2.538 \times 10^{4} \mathrm{~kg} / \mathrm{m}^{2} s$. The minimum value of longitudinal frequency is $0.415613 \mathrm{GHz}$, radial frequency is $0.414408 \mathrm{GHz}$ and torsional is $0.414528 \mathrm{GHz}$ and the maximum value of longitudinal frequency is $3.02849 \mathrm{GHz}$, radial frequency is $0.425151 \mathrm{GHz}$ and for torsional mode it is $0.483036 \mathrm{GHz}$, while for $n=0, E=0$ and $\eta=0$ the minimum value of longitudinal, radial and torsional mode are $0.031635,0.009999$ and 0.00031659 , respectively, and the maximum value of longitudinal frequency is $3.00000 \mathrm{GHz}$, radial frequency is $0.0949747 \mathrm{GHz}$ and for torsional mode it is $0.298174 \mathrm{GHz}$. These results show that maximum eigen frequency for longitudinal and torsional modes, when $n=0$ is not affected considerably but radial mode is affected with considerable amount.

TABLE 2. Viscoelastic material parameters

\begin{tabular}{lcc}
\hline \multicolumn{1}{c}{ Parameters } & Symbols & Numerical values \\
\hline Elastic coefficient & $K$ & $111.59 \pm 49.9 \mathrm{~kg} / \mathrm{ms}^{2}$ \\
Viscous coefficient & $\eta$ & $55.96 \pm 38.02 \mathrm{~kg} / \mathrm{ms}^{2}$ \\
\hline
\end{tabular}

TABLE 3. Frequency modes for embedded microtubules for $\mathrm{n}=0,1,2,3,4$

\begin{tabular}{|c|c|c|c|c|c|}
\hline $\mathrm{n}=0$ & \multicolumn{2}{|c|}{ Free medium } & & \multicolumn{2}{|c|}{ Within medium } \\
\hline Frequency & Minimum & Maximum & Frequency & Minimum & Maximum \\
\hline L- mode & 0.0316348 & 2.99999 & L- mode & 0.415613 & 3.02849 \\
\hline $\mathrm{R}$ - mode & 0.000316582 & 0.0949747 & $\mathrm{R}$ - mode & 0.414408 & 0.425151 \\
\hline T- mode & 0.009999 & 0.298174 & T- mode & 0.414528 & 0.483036 \\
\hline $\mathrm{n}=1$ & \multicolumn{2}{|c|}{ Free medium } & & \multicolumn{2}{|c|}{ Within medium } \\
\hline Frequency & Minimum & Maximum & Frequency & Minimum & Maximum \\
\hline L- mode & 0.0447234 & 3.00017 & L- mode & 0.416814 & 3.02865 \\
\hline R-mode & 0.00019369 & 0.100003 & R- mode & 0.414407 & 0.426303 \\
\hline T- mode & 0.0331761 & 0.259947 & T- mode & 0.415733 & 0.489189 \\
\hline$n=2$ & \multicolumn{2}{|c|}{ Free medium } & & \multicolumn{2}{|c|}{ Within medium } \\
\hline Frequency & Minimum & Maximum & Frequency & Minimum & Maximum \\
\hline L- mode & 0.0707259 & 3.00067 & L- mode & 0.420399 & 3.02915 \\
\hline R-mode & 0.00236568 & 0.113826 & R-mode & 0.414414 & 0.429756 \\
\hline $\mathrm{T}$ - mode & 0.0649495 & 0.292426 & T- mode & 0.419328 & 0.507195 \\
\hline $\mathrm{n}=3$ & \multicolumn{2}{|c|}{ Free medium } & & \multicolumn{2}{|c|}{ Within medium } \\
\hline Frequency & Minimum & Maximum & Frequency & Minimum & Maximum \\
\hline L- mode & 0.100033 & 3.0015 & L- mode & 0.42631 & 3.0299 \\
\hline R-mode & 0.00660 & 0.1338257 & R- mode & 0.41446 & 0.4355 \\
\hline T- mode & 0.09540 & 0.3397 & T- mode & 0.42535 & 0.5358 \\
\hline $\mathrm{n}=4$ & \multicolumn{2}{|c|}{ Free medium } & & \multicolumn{2}{|c|}{ Within medium } \\
\hline Frequency & Minimum & Maximum & Frequency & Minimum & Maximum \\
\hline L- mode & 0.130434 & 3.00267 & L- mode & 0.43445 & 3.03113 \\
\hline R-mode & 0.0126219 & 0.157696 & R- mode & 0.4146 & 0.443398 \\
\hline T- mode & 0.126922 & 0.396638 & T- mode & 0.433408 & 0.573633 \\
\hline
\end{tabular}




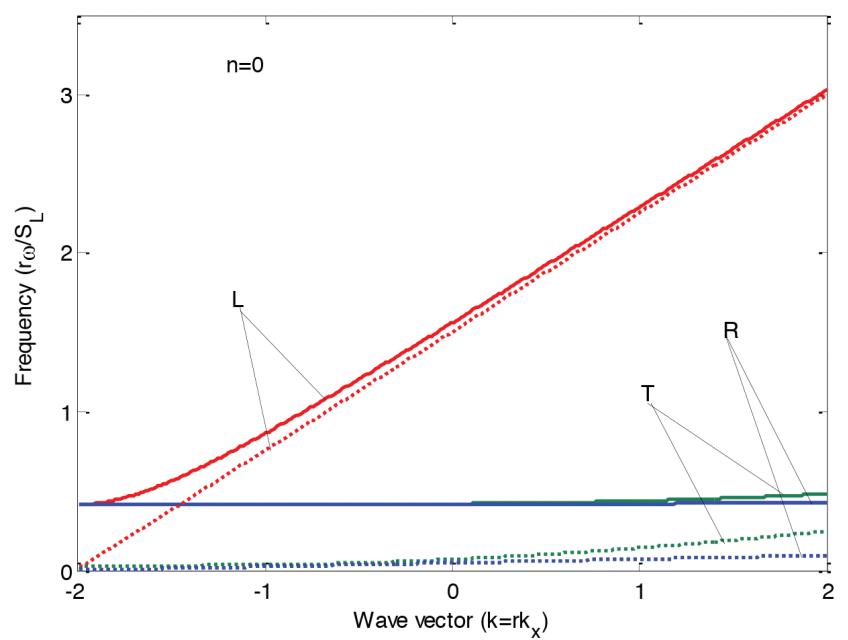

FIGURE 1. Effect of elastic medium on vibration of microtubules. Dotted lines for orthotropic model and solid lines for orthotropic Kelvin - like model for $\mathrm{n}=0$ (L: Longitudinal modes, $\mathrm{T}$ : Torsional modes, R: Radial modes)

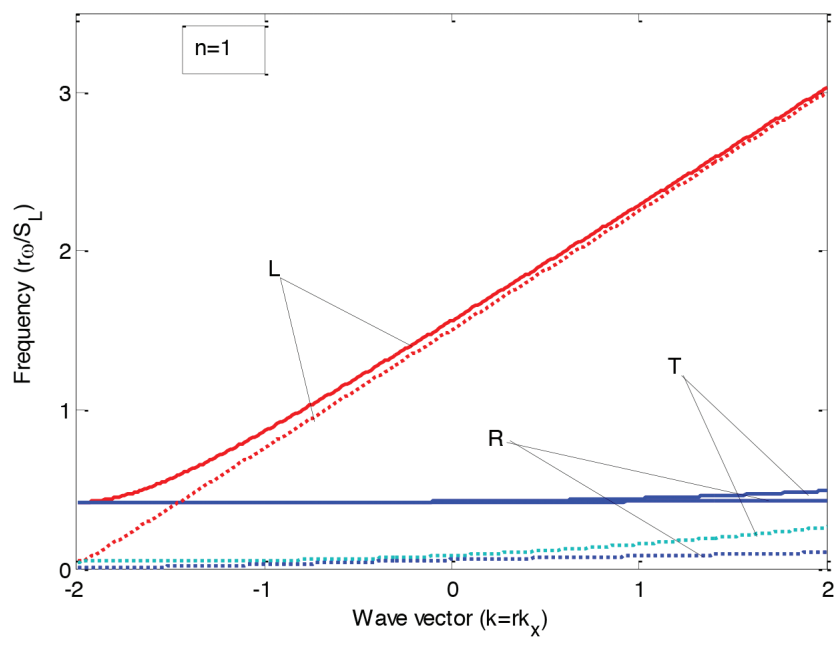

For $\mathrm{n}=2$ and 3 similar behavior is shown which is indicated in the figures and above tables

FIGURE 2. Effect of elastic medium on vibration of MTs. Dotted lines for orthotropic model and solid lines for present model for $\mathrm{n}=1$ (L: Longitudinal modes, T: Torsional modes, R: Radial modes)

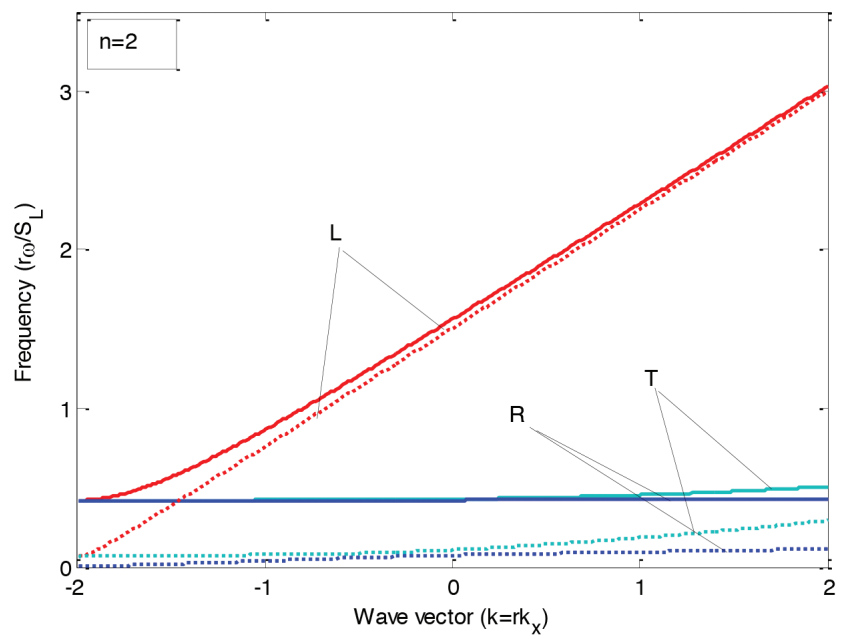

FIGURE 3. Effect of Elastic medium on vibration of MTs. Dotted lines for Orthotropic model and solid lines for present for $\mathrm{n}=2$ (L: Longitudinal modes, $\mathrm{T}$ : Torsional modes, R: Radial modes) 


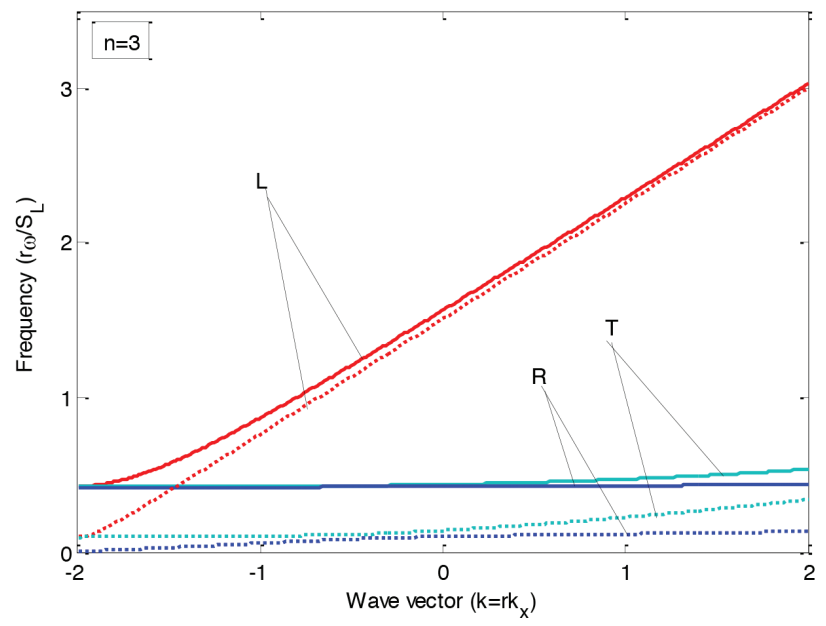

FIGURE 4. Effect of elastic medium on vibration of MTs. Dotted lines for Orthotropic model and solid lines for present model for $\mathrm{n}=3$ (L: Longitudinal modes, $\mathrm{T}$ : Torsional modes, R: Radial modes)

When $n=1$ minimum value for three modes in case of present model are $\mathrm{L}=0.416814 \mathrm{GHz}, \mathrm{R}=0.414407 \mathrm{GHz}$ and $\mathrm{T}=0.415733 \mathrm{GHz}$ while the maximum values are $\mathrm{L}=3.02865 \mathrm{GHz}, \mathrm{R}=0.426303 \mathrm{GHz}$ and $\mathrm{T}=0.489189 \mathrm{GHz}$ which is different from the previous orthotropic elastic shell model for free microtubule especially for radial and circumferential modes (Figures 2-4).

\section{CONCLUSION}

We found that the Elastic modulus $(E)$ and viscosity $(\eta)$ both affected radial mode more than torsional and longitudinal mode of vibration. This is because of the fact that flexural rigidity of MTs is increased with the coupling of surrounding matrix. It is clear from the figures that the dynamic behavior of the embedded MTs in the viscoelastic foundation is very sensitive to the foundation parameters. Obtained results have been evaluated against those available in the literature for free microtubules. Our theoretical and numerical results confirm the experimental findings by Leonova et al. (2003). Therefore, surrounding matrix affects the vibration of MTs during its transportation of cellular organelles and other functioning. So obtained minimum and maximum values of eigen frequencies are helpful in many biological problems to overcome malfunctioning of cell structure and other functional problems in cytoskeleton.

\section{REFERENCES}

Adames, N.R. \& Cooper, J.A. 2000. Microtubule interactions with the cell cortex causing nuclear movements in Saccharomyces cerevisiae. J. Cell Biol. 149(4): 863-874.

Boykov, I., Boykova, A. \& Ventsel, E. 2004. Fundamental solutions for thick sandwich plates. Engineering Analysis with Boundary Elements 28(12): 1437-1444.

Brangwynne, C.P., MacKintosh, F.C., Kumar, S., Geisse, N.A., Talbot, J., Mahadevan, L., Parker, K.K., Ingber, D.E. \& Weitz, D.A. 2006. Microtubules can bear enhanced compressive loads in living cells because of lateral reinforcement. J. Cell Biol. 173(5): 733-741.

Burton, G.W. \& Forbes, I. 1960. The genetics and manipulation of obligate apomixis in common Bahia grass Pas-palum notatum Flügge. Paper presented at the Proceedings of the Eighth International Grassland Congress held at the University of Reading, England, 11-21 July.

Chung-Davidson, Y.W., Huertas, M. \& Li, W. 2010. A review of research in fish pheromones. In Chemical Communication in Crustaceans, edited by Breithaupt, T. \& Thiel, M. New York: Springer. pp. 467-482.

Feldhendler, D. 2002. Augusto Boal and Jacob L.Moreno: Theatre and therapy. In Playing Boal: Theatre, Theraphy \& Activitism, edited by Schutzman, M. \& Cohen-Cruz, J. London: Routledge. pp. 97-119.

Felgner, P., Barenholz, Y., Behr, J., Cheng, S., Cullis, P., Huang, L., Jessee, J.A., Seymour, L., Szoka, F., Thierry, A.R., Wagner, E. \& Thierry, A. 1997. Nomenclature for synthetic gene delivery systems. Human Gene Therapy 8(5): 511-512.

Forbes, J., Russell, J., Miyahara, S., Zhang, X., Palo, S., Mlynczak, M., Mertens. C.J. \& Hagan, M. 2006. Tropospherethermosphere tidal coupling as measured by the SABER instrument on TIMED during July-September 2002. Journal of Geophysical Research: Space Physics 111(A10). https:// doi.org/10.1029/2005JA011492.

Hardin, R. 2015. Collective Action. New York: RFF Press.

Kiyoi, H., Naoe, T., Nakano, Y., Yokota, S., Minami, S., Miyawaki, S., Asou, N., Kuriyama, K., Jinnai, I., Shimazaki, C., Akiyama, H., Saito, K., Oh, H., Motoji, T., Omoto, E., Saito, H., Ohno, R. \& Ueda, R. 1999. Prognostic implication of FLT3 and N-RAS gene mutations in acute myeloid leukemia. Blood 93(9): 3074-3080.

Kreider, J.C. \& Blumberg, M.S. 2005. Geotaxis and beyond: Commentary on Motz and Alberts. Neurotoxicology and Teratology 27(4): 535-538.

Leonova, A., Pokorny, J. \& Smith, V.C. 2003. Spatial frequency processing in inferred PC-and MC-pathways. Vision Research 43(20): 2133-2139.

Meyers, M.A. \& Chawla, K.K. 1999. Mechanical Behavior of Materials. Englewood Cliffs: Prentice-Hall.

Morehouse, B.J., Carter, R.H. \& Sprouse, T.W. 2000. The implications of sustained drought for transboundary water 
management in Nogales, Arizona, and Nogales, Sonora. Natural Resources Journal 40(4): 783-817.

Nogales, E., Whittaker, M., Milligan, R.A. \& Downing, K.H. 1999. High-resolution model of the microtubule. Cell 96(1): 79-88.

Pet-Soede, C., Cesar, H.S. \& Pet, J. 1999. An economic analysis of blast fishing on Indonesian coral reefs. Environmental Conservation 26(2): 83-93.

Schoutens, W. 2005. Moment swaps. Quantitative Finance 5(6): 525-530.

Shah, S., Li, J., Moffatt, B.A. \& Glick, B.R. 1998. Isolation and characterization of ACC deaminase genes from two different plant growth-promoting rhizobacteria. Canadian Journal of Microbiology 44(9): 833-843.

Sharma, P., Khatri, V.K., Gu, X., Song, Y., Shen, M.L., RiggsSauthier, J., Anand, N.K., Kozlowski, A., Odinecs, A. \& Riley, T.A. 2019. Derivatives of 6-(2, 3-dichlorophenyl)-1, 2, 4-triazin-5-amine: Google Patents.

Shen, R. \& Andrews, S.A. 2011 . NDMA formation kinetics from three pharmaceuticals in four water matrices. Water Research 45(17): 5687-5694.

Sirenko, Y.M., Stroscio, M.A. \& Kim, K. 1996. Elastic vibrations of microtubules in a fluid. Physical Review E 53(1): 1003.

Taj, M. \& Zhang, J. 2014. Analysis of wave propagation in orthotropic microtubules embedded within elastic medium by Pasternak model. J. Mech. Behav. Biomed. Mater. 30: 300-305

Taj, M. \& Zhang, J. 2012. Analysis of vibrational behaviors of microtubules embedded within elastic medium by Pasternak model. Biochemical and Biophysical Research Communications 424(1): 89-93.

Taj, M. \& Zhang, J.Q. 2011. Buckling of embedded microtubules in elastic medium. Applied Mathematics and Mechanics 32(3): 293-300.

Van Buren, M.E. \& Erskine, W. 2002. The 2002 ASTD state of the industry report. Alexandria, VA: American Society of Training and Development.

Van Buren, V., Odde, D.J. \& Cassimeris, L. 2002. Estimates of lateral and longitudinal bond energies within the microtubule lattice. Proceedings of the National Academy of Sciences 99(9): 6035-6040

Wang, Y., Kong, L.J., Li, C. \& Bureau, D.P. 2006. Effect of replacing fish meal with soybean meal on growth, feed utilization and carcass composition of cuneate drum (Nibea miichthioides). Aquaculture 261(4): 1307-1313.
Yang, X., Schadt, E.E., Wang, S., Wang, H.,Arnold, A.P., IngramDrake, L., Drake, T.A. \& Lusis, A.J. 2006. Tissue-specific expression and regulation of sexually dimorphic genes in mice. Genome Research 16(8): 995-1004.

Zhang, B., Georgiev, O., Hagmann, M., Günes, Ç., Cramer, M., Faller, P., Vasák, M. \& Schaffner, W. 2003. Activity of metalresponsive transcription factor 1 by toxic heavy metals and $\mathrm{H} 2 \mathrm{O} 2$ in vitro is modulated by metallothionein. Molecular and Cellular Biology 23(23): 8471-8485.

Zhao, Z., Dua, D. \& Singh, S. 2017. Generating natural adversarial examples. arXiv preprint arXiv:1710.11342.

Zheng, J., Trafny, E.A., Knighton, D.R., Xuong, N.H., Taylor, S.S., Ten Eyck, L.F. \& Sowadski, J.M. 1993. 2.2 A refined crystal structure of the catalytic subunit of cAMP-dependent protein kinase complexed with MnATP and a peptide inhibitor. Acta Crystallographica Section D: Biological Crystallography 49(3): 362-365.

Zhou, Y., Wu, Y., Yang, L., Fu, L., He, K., Wang, S., Hao J., Chen, J. \& Li, C. 2010. The impact of transportation control measures on emission reductions during the 2008 Olympic Games in Beijing, China. Atmospheric Environment 44(3): 285-293.

Muhammad Safeer \& Muhammad Taj*

Department of Mathematics

The University of Azad Kashmir

Muzaffarabad 13100

Pakistan

Muhammad Safeer

Department of Mathematics

University of Poonch Rawalwkot

Azad Kashmir

Pakistan

*Corresponding author; email: Muhammad_taj75@yahoo.com

Received: 5 March 2019

Accepted: 23 December 2019 